\title{
Nitrous oxide fluxes in soil as influenced by compaction
}

\author{
R. BHANDRAL ${ }^{1}$, S. SAGGAR ${ }^{2}$, N.S.BOLAN ${ }^{1}$ and M.J.HEDLEY ${ }^{1}$ \\ ${ }^{1}$ Soil \& Earth Science Group, Massey University, Palmerston North \\ ${ }^{2}$ Landcare Research, PB 11052, Palmerston North
}

Rita.Bhandral.1@uni.massey.ac.nz

\begin{abstract}
In grazed-pastures animal treading is an important cause of soil compaction. Soil compaction influences the denitrification rate as well as the amounts of nitrous oxide $\left(\mathrm{N}_{2} \mathrm{O}\right)$ and dinitrogen $\left(\mathrm{N}_{2}\right)$ production in the soil mainly through its impact on soil moisture conditions and porosity. A field experiment was undertaken to determine the loss of nitrogen $(\mathrm{N})$ through $\mathrm{N}_{2} \mathrm{O}$ emission from different $\mathrm{N}$ sources as affected by a compaction treatment. Experiment comprised of two main treatments (uncompacted and compacted) to which four $\mathrm{N}$ sources (cattle urine, potassium nitrate, ammonium sulphate and urea at the rate of $600 \mathrm{~kg} \mathrm{~N} / \mathrm{ha}$ ) and a control (water only) were applied, each replicated four times. Compaction was obtained through driving close parallel tracks by the wheels of the vehicle. Various soil properties related to soil compaction (bulk density, water filled pore space (WFPS), oxygen diffusion rate (ODR)) were measured. The $\mathrm{N}_{2} \mathrm{O}$ fluxes were measured for 3 months (between $10^{\text {th }}$ September and $4^{\text {th }}$ December, 2002) using closed chamber technique.

Overall, the bulk density of compacted soil was $12.8 \%$ higher than that of the uncompacted soil. Results suggest that maximum compaction occurred in the top 0-2 cm layer. Soil matric potential measured at the $0-5 \mathrm{~cm}$ soil depth suggests that uncompacted soil had lower water content, except at low matric suctions, than compacted soil. The ODR in uncompacted soil was $79.3 \%$ higher than that in the compacted soil. Compaction caused a seven fold increase in $\mathrm{N}_{2} \mathrm{O}$ emission. Nitrate source was the most effective of all the treatments in causing potential emission. Under compacted soil $9.87 \%$ of the total $\mathrm{N}$ applied in form of nitrate was emitted whereas under uncompacted soil this loss was only $0.54 \%$. $\mathrm{N}_{2} \mathrm{O}$ loss was found to decrease progressively from the time of application of $\mathrm{N}$ treatments. Total $\mathrm{N}_{2} \mathrm{O}$ emission for the three month experimental period ranged from 2.62 to $61.74 \mathrm{~kg} \mathrm{~N} 2 \mathrm{O}-\mathrm{N} / \mathrm{ha}$ for compacted soil and 1.12 to $4.37 \mathrm{~kg} \mathrm{~N}$ O-N/ha for uncompacted soil.
\end{abstract}

Keywords: compaction, grazed pastures, Nfertilisers, nitrous oxide emissions, urine-N

\section{Introduction}

Return of gaseous $\mathrm{N}$ (mainly as $\mathrm{N}_{2}$ ) to the atmosphere via denitrification is a major pathway for $\mathrm{N}$ loss from soils of natural and agricultural ecosystems (Koops \& Oenema 1994). Nitrous oxide $\left(\mathrm{N}_{2} \mathrm{O}\right)$, a minor product of denitrification is an important greenhouse gas and it interferes with the formation of stratospheric ozone and also accelerates its destruction (Crutzen 1976). Increasing atmospheric concentrations of $\mathrm{N}_{2} \mathrm{O}$ are expected to play a key role in altering the earth's climate (i.e. global warming). It is therefore important to quantify the sources and sinks of this gas and to examine the influence of anthropogenic activities on the exchange rates.

The emission of $\mathrm{N}_{2} \mathrm{O}$ from soils, during nitrification and denitrification is controlled by factors such as oxygen supply, water content, temperature, soil $\mathrm{pH}$, organic matter, and $\mathrm{N}$ sources. In addition to these, several soil management practices such as tillage, soil compaction (Staley et al. 1990; Hansen et al. 1993), irrigation and drainage (Mosier et al. 1986) affect the production and release of $\mathrm{N}_{2} \mathrm{O}$ by influencing soil's physical conditions (i.e. aeration and soil water content). Soil surface conditions can have a major impact on denitrification through its direct effect on soil aeration and indirect effect on $\mathrm{N}$ transformations (Arah et al. 1991). Compaction is a particular problem in moist, temperate climates (Douglas \& Crawford 1993). It alters soil $\mathrm{N}$ transformation rates and processes, especially mineralization and denitrification, which leads to reduced $\mathrm{N}$ uptake by plants (see Table 1). These changes can mostly be attributed to changes in soil moisture level resulting from increased bulk density (reduced porosity) (Linn \& Doran 1984.). The negative impact of soil compaction on crop production is well established (Bakken et al. 1987). Soil compaction has also been shown to promote denitrification. For example, McTaggart et al. (1997) and Hansen et al. (1993) observed that soil compaction increased $\mathrm{N}_{2} \mathrm{O}$ emission by $100 \%$ from an imperfectly drained clay loam and by $36 \%$ on a sandy loam soil, respectively.

In grazed-pastures, animal treading is an important cause of soil compaction. Treading damages plants directly and also has an indirect effect on pasture growth through soil compaction and puddling (Tollner et al. 1990). In New Zealand, in an all-grass wintering system, cattle are often hard grazed on pasture 


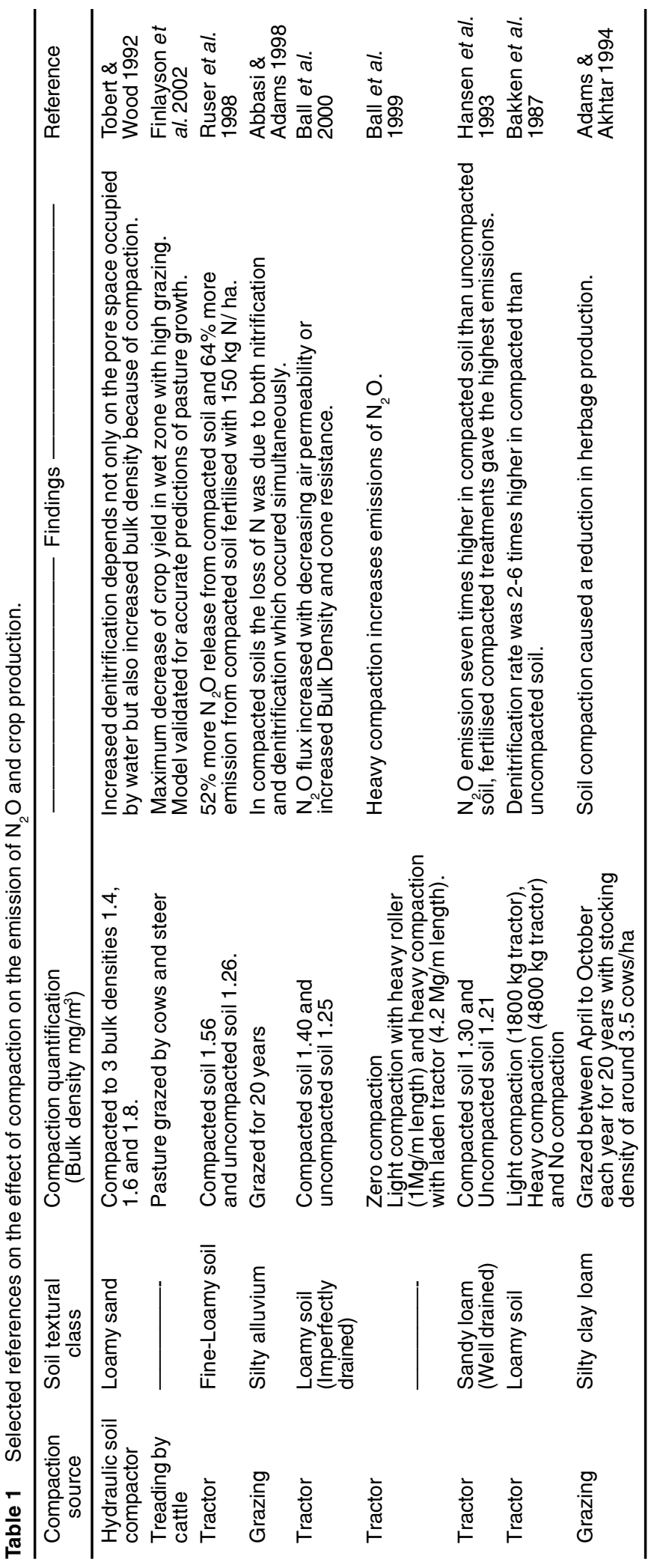

throughout winter and early spring. In this system, especially when the soil is wet, cattle treading causes significant soil compaction. More recently farmers in New Zealand have increased the cattle: sheep ratio in order to maintain profitability and to reduce labour requirements (Betteridge et al. 1999). As cattle exert greater static loadings (up to $400 \mathrm{kPa}$ ) than sheep (50-125 kPa) (Willatt \& Pullar 1983; Thomas et al. 1990), this increased ratio has increased the risk of damage to soils. Moreover the dynamic loading from moving animals can be more than double those of stationary animals, and on wet or loose soils bearing capacities may be less than $100 \mathrm{kPa}$ (Chancellor et al. 1962).

Greater understanding of the effect of soil compaction on $\mathrm{N}_{2} \mathrm{O}$ emissions is needed to devise strategies for reducing these emissions. The present study was, therefore, undertaken to determine the loss of $\mathrm{N}$ through $\mathrm{N}_{2} \mathrm{O}$ emission from different $\mathrm{N}$ sources as affected by compaction treatment. The effect of compaction on $\mathrm{N}_{2} \mathrm{O}$ emission was examined in relation to its effect on some of the soil physical properties.

\section{Material and methods}

A field experiment was conducted during September-December 2002 on sheep-grazed permanent legume-based pasture at Massey University Frewens Research Block, Turitea campus, Palmerston North (New Zealand). A plot was fenced off a week before the commencement of the experiment to avoid further stock access during the experimental period. The soil at this site is a Manawatu fine sandy loam, classified as weathered fluvial recent soil. Grid reference of the location is NZMS1, N149/101305 (Hewitt1993) at latitude of $40^{\mathrm{E} \%} \% 23$ 'S and longitude of $175^{\mathrm{E} \%} \% 37^{\prime} \mathrm{E}$. The research farm is located $40 \mathrm{~m}$ above mean sea level. The 30 years mean rainfall during September-December ranges between $82-90 \mathrm{~mm} / \mathrm{month}$ and is fairly evenly distributed. The rainfall during 2002 was $73 \mathrm{~mm}, 67.6 \mathrm{~mm}$ and $45.4 \mathrm{~mm}$ for the months of September, October and November, respectively. 
The experiment comprised of two main treatments (uncompacted and compacted) to which four $\mathrm{N}$ sources (natural cattle urine, potassium nitrate, ammonium sulphate and urea all at the rate of $600 \mathrm{~kg}$ $\mathrm{N} / \mathrm{ha}$ and a control (water only) were applied, each replicated four times. Compaction was obtained through driving close parallel tracks by the wheels of the vehicle. Total pressure of the vehicle on the ground was $632 \mathrm{kPa}$.

\section{Nitrous oxide measurement}

The $\mathrm{N}_{2} \mathrm{O}$ fluxes were measured between 10 September and 4 December 2002 using the closed chamber technique (Saggar et al. 2002). Four chambers per N treatment were used. The chambers, $250 \mathrm{~mm}$ in diameter, were inserted about $100 \mathrm{~mm}$ into the soil. Chamber heights were measured to calculate the volume of each chamber. During the first week measurements of the $\mathrm{N}_{2} \mathrm{O}$ emissions were made daily to capture major changes in $\mathrm{N}_{2} \mathrm{O}$ fluxes. This was followed by measurements on alternate days for two months and then by once a week for rest of the experimental period as the fluxes decreased, approaching the background levels. Everyday after sealing the chamber with lids, three gas samples were taken from each chamber at times $t_{0}, t_{30}$ and $t_{60}$ (Time $0 \mathrm{~min}, 30 \mathrm{~min}$ and $60 \mathrm{~min}$ after closing of the chamber, respectively).The gas samples collected were then analyzed using a Shimadzu GC-17A gas chromatograph with a ${ }^{63} \mathrm{Ni}-E l e c t r o n$ capture detector and $\mathrm{N}_{2} \mathrm{O}\left(\mathrm{mg} / \mathrm{m}^{2} / \mathrm{hr}^{1}\right)$ flux was estimated from the measurements made at three time periods $\left(t_{0}, t_{30}\right.$ and $\left.\mathrm{t}_{60}\right)$.

\section{Soil sampling}

Soil bulk density of the compacted and uncompacted treatments was determined using undisturbed soil cores. Cores were $4.75 \mathrm{~cm}$ diameter and $2 \mathrm{~cm}$ in height. Four soil samples were collected randomly on everyday of $\mathrm{N}_{2} \mathrm{O}$ measurement from each treatment from $0-5 \mathrm{~cm}$ and $5-10 \mathrm{~cm}$ depths to determine soil water content. Field moist soil samples were weighed $\left(\mathrm{M}_{\mathrm{t}}\right)$ and oven dried $\left(105^{\circ} \mathrm{C}\right)$ to a constant mass $\left(\mathrm{M}_{\mathrm{s}}\right)$. Gravimetric soil water content (SWC) was calculated:

$\mathrm{SWC}=\left(\left(\mathrm{M}_{\mathrm{t}}-\mathrm{M}_{\mathrm{s}}\right) / \mathrm{M}_{\mathrm{s}}\right) \times 100$

The volumetric soil water content was then calculated by multiplying the gravimetric SWC with the soil bulk density. The WFPS was calculated as follows:

WFPS $=[$ (gravimetric water content $\mathrm{x}$ soil bulk density) / total soil porosity]

Where, total soil porosity was calculated by the formula

Soil Porosity $=1-$ (bulk density/ particle density); assumed $2.65 \mathrm{~g} / \mathrm{cm}^{3}$ as the particle density of the soil.

\section{Oxygen diffusion rate (ODR)}

ODR was measured by using the 'Jensen Instruments Microelectrodes' (Glinski \& Stepniewski 1985). It was measured in the field in the beginning of the experiment at 5 and $10 \mathrm{~cm}$ soil depth, replicated four times. The ODR was calculated using the equation:

ODR $=0.059 \times$ observed microelectrode current in microamperes $\left(\mu \mathrm{g} / \mathrm{cm}^{2} / \mathrm{min}\right)$

\section{Statistical methods}

A split- plot design with compaction as the main treatment and $\mathrm{N}$ sources as sub plot treatment. Means and standard error of means were calculated for bulk density, WFPS and water retentivity values. Total emission data was subjected to an analysis of variance to determine the statistical significance of compaction $(\mathrm{n}=24)$ and $\mathrm{N}$ sources $(\mathrm{n}=8)$, using SAS for Windows software package. Calculated indices were analysed using a test of least significant difference (LSD). The 5\% confidence level is regarded as statistically significant.

\section{Results and discussion \\ Soil physical characteristics}

Compaction was successfully achieved through driving close parallel tracks as indicated by the changes in soil bulk density (Table 2), soil matric potential (Figure 2) and ODR data.

Overall, the bulk density of compacted soil was $11.0 \%$ higher than that of the uncompacted soil. Although within 0-6 cm soil depth, bulk density under compacted soil was higher in all the three soil depths $(0-2 \mathrm{~cm}, 2-4 \mathrm{~cm}, 4-6 \mathrm{~cm})$, the difference between the compacted and uncompacted soils decreased with depth (Table 2). These results suggest that maximum compaction occurred in the top 0-2 cm layer. Similar changes in bulk density caused by compaction have been reported elsewhere (Ball et al. 2000; Tobert \& Wood 1992).

Soil water content measured at the three matric suctions of $0.1,1$ and 15 bar at the $0-5 \mathrm{~cm}$ soil depth suggested that uncompacted soil had lower water content, except at low matric suctions, than compacted soil (Figure 2). At 0.1 bar suction, which represents field capacity, water content in uncompacted soil was $22.7 \%$ higher than the compacted soil. At the 1 bar and 15 bar suctions compacted soil had $15.6 \%$ and $4.3 \%$ higher water content values than in uncompacted soil. The results could be explained on the basis that compaction is known to decrease total porosity by decreasing the number of large interaggreate pores. It is the macropores that drain at 
low suction ranges hence lower water content was recorded for compacted soils at 0.1 bar suction. On the other hand, the volume of intermediate size pores is likely to be somewhat greater in a compacted soil as some of the original large pores have been squeezed to intermediate size pores by compaction. This supports the results of water retention obtained at 1 bar. At high suction value of 15 bar the water content was found to be similar in both compacted and uncompacted soils (Figure 2). Soil moisture in uncompacted soil at 0.1 bar suction was found to be significantly higher than compacted soil.

ODR in uncompacted soil was $90.9 \%$ higher than that in compacted soil suggesting that soil was compacted. The mean ODR value at $5 \mathrm{~cm}$ soil depth was found to be $0.22( \pm 0.16)$ and $0.42( \pm 0.22)$ $\mu \mathrm{g} / \mathrm{cm}^{2} / \mathrm{min}$ for compacted and uncompacted soil, respectively. ODR is a function of total porosity in the soil, which in turn is influenced by compaction. ODR is also affected by the water content of the soil. During the initial period of the experiment heavy rains caused ponding of water in compacted soil leading to completely saturated soil. Differences in ODR between compacted and uncompacted can also be attributed to this.

Water filled pore space (WFPS) differed slightly between compacted soil $(0.73$ to $1.30)$ and uncompacted soil (0.72 to 1.17). The compacted soil remained saturated for most of the study period. Torbert \& Wood (1992) reported that WFPS is useful as an index of soil $\mathrm{N}$ loss via denitrification, and bulk density plays a major role in controlling $\mathrm{N}_{2} \mathrm{O}$ emissions.

\section{$\mathrm{N}_{2} \mathrm{O}$ emission}

\section{Effect of compaction}

The total $\mathrm{N}_{2} \mathrm{O}$ fluxes for the entire experimental period were found to be in the range of $2.62( \pm 0.72)$ to 61.74 $( \pm 10.83) \mathrm{kg} \mathrm{N} / \mathrm{O}-\mathrm{N} / \mathrm{ha}$ for compacted soil and 1.12 $( \pm 0.36)$ to $4.37( \pm 0.92) \mathrm{kg} \mathrm{N}_{2} \mathrm{O}-\mathrm{N} /$ ha for uncompacted soil (Table 3). The total $\mathrm{N}_{2} \mathrm{O}$ losses for compacted soil were found to be significantly higher than uncompacted soil (Figures 3 and 4). Compaction caused a seven-fold increase in $\mathrm{N}_{2} \mathrm{O}$ emission irrespective of $\mathrm{N}$ source (Table 3). Plausible explanation for these results is that soil compaction
Table 2 Distribution of bulk density $\left(\mathrm{mg} / \mathrm{m}^{3}\right)$ with depth for compacted and uncompacted soil.

\begin{tabular}{llll}
\hline Depth $(\mathrm{cm})$ & $\begin{array}{l}\text { Bulk density } \\
\text { compacted }\end{array}$ & Uncompacted & Mean \\
\hline $0-2$ & 1.40 & 1.18 & 1.29 \\
$2-4$ & 1.30 & 1.18 & 1.24 \\
$4-6$ & 1.23 & 1.19 & 1.21 \\
Mean & 1.31 & 1.18 & \\
LSD(0.05) & LSD $(0.05)$ & LSD $(0.05)$ & LSD $(0.05)$ \\
Compacted vs. & Depth & Compaction vs. & Depth vs. \\
uncompacted & & depth & compaction \\
$\mathrm{n}=9$ & $\mathrm{n}=3$ & $\mathrm{n}=6$ & $\mathrm{n}=6$ \\
0.04 & 0.01 & 0.03 & 0.03 \\
\hline
\end{tabular}

Figure 1 Distribution of rainfall and WFPS during the experiment.

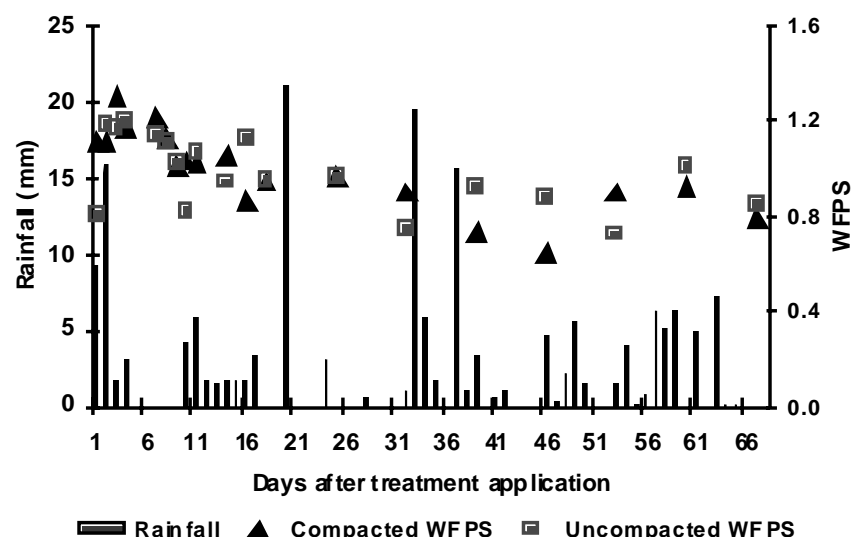

Figure 2 Effect of compaction on soil water retentivity at $0-5 \mathrm{~cm}$ depth. Each value represents a mean of four replicates with standard deviation shown by vertical bars.

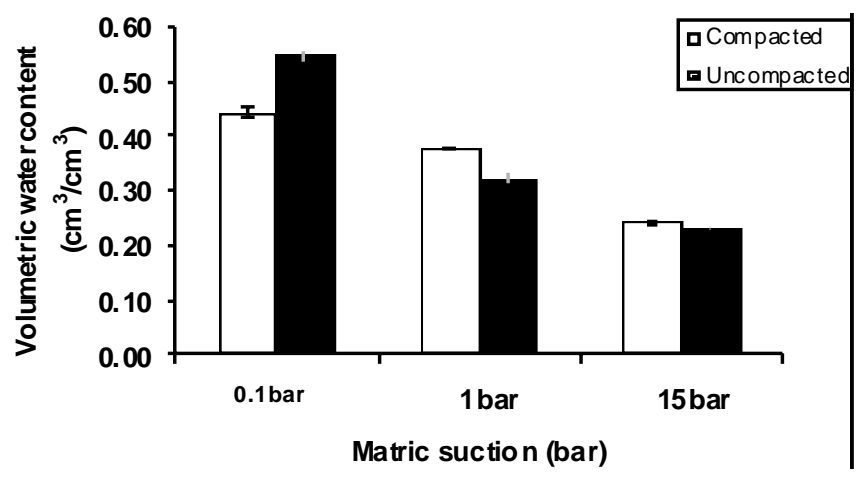

shifted soil conditions to an anaerobic state, resulting in reduced aerobic microbial activity and increased denitrification. Both decreased aerobic respiration and increased denitrification with increasing WFPS are caused by a reduction in oxygen diffusion through soil (Doran et al. 1988). Compacted soil remained saturated for majority of the time during our study and is likely to have reduced the proportion of larger 
Table 3 Total $\mathrm{N}_{2} \mathrm{O}-\mathrm{N}$ emitted ( $\mathrm{kg} \mathrm{N} / \mathrm{ha}$ ) over the experimental period from the N Sources applied under compacted and uncompacted soil.

\begin{tabular}{lccc}
\hline Treatment & \multicolumn{2}{c}{ Main Plots } & \\
\cline { 2 - 3 } & Compacted & Uncompacted & Mean \\
\hline Urine & 9.17 & 2.94 & 6.05 \\
Nitrate & 61.74 & 4.37 & 33.05 \\
Ammonium & 9.17 & 2.64 & 5.90 \\
Urea & 9.11 & 2.13 & 5.62 \\
Water & 2.62 & 1.12 & 1.87 \\
Mean & 18.35 & 2.64 & \\
LSD(0.05) & LSD(0.05) & & \\
Compacted vs. & Compacted + & Treatments & \\
uncompacted & uncompacted mean & $\mathrm{n}=4$ & \\
$\mathrm{n}=24$ & $\mathrm{n}=8$ & & \\
3.43 & 3.93 & 5.94 & \\
\hline
\end{tabular}

Figure $3 \quad \mathrm{~N} O$ fluxes $(\mathrm{kg} \mathrm{N} / \mathrm{ha} / \mathrm{d})$ under the compacted treatment. Each value represents a mean of four replicates with standard deviation shown by vertical bars.

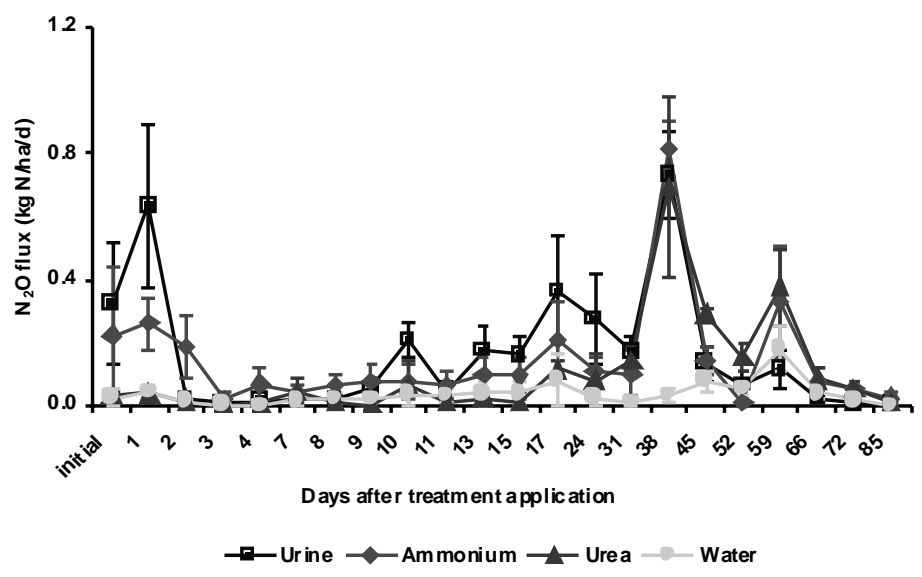

Figure $4 \quad \mathrm{~N} 2 \mathrm{O}$ fluxes $(\mathrm{kg} \mathrm{N} / \mathrm{ha} / \mathrm{d})$ under the uncompacted treatment. Each value represents a mean of four replicates with standard deviation shown by vertical bars.

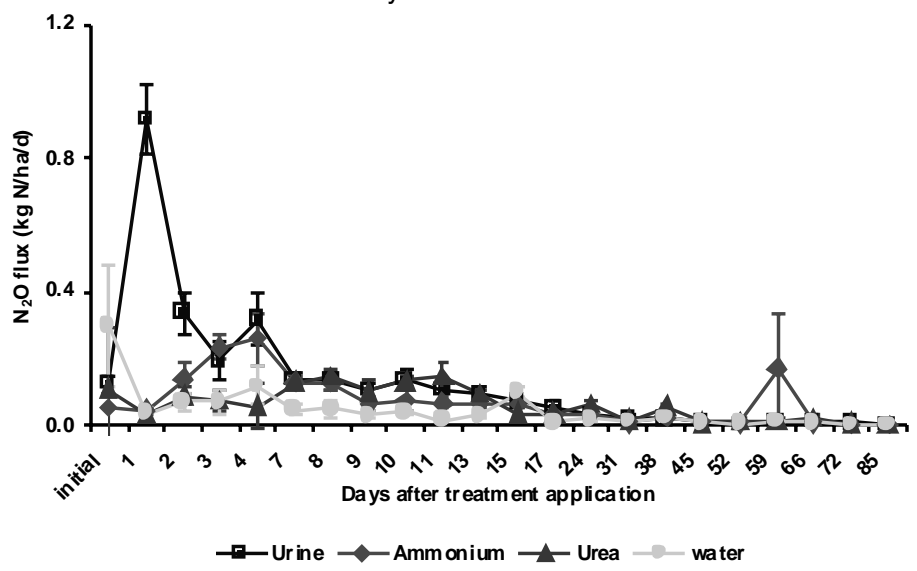

pores, resulting in more soil pores being filled with water. Also the continuity of pores was probably reduced with increasing bulk density, resulting in reduced oxygen diffusion.

An initial low emission period (for all $\mathrm{N}$ sources except nitrate) was found under compacted soil, but not under uncompacted soil (Figures 3 and 4). During the initial phase of the experiment heavy rains caused complete saturation of the soil as shown by high WFPS. Compaction caused reduced infiltration (not measured), leading to ponding of water within the chambers. These reducing conditions caused some pasture death and lowered the nitrification rate. These conditions are consistent with flooded hoof marks left in pastures badly damaged by winter cattle treading. As the soil conditions improved, the nitrification process increased, leading to an increase in $\mathrm{N}_{2} \mathrm{O}$ emission. As completely saturated conditions were not found under uncompacted soils, the emissions were much more consistent.

\section{Effect of $\mathbf{N}$ sources}

The $\mathrm{N}$ sources were found to affect the $\mathrm{N}_{2} \mathrm{O}$ emissions, with the effect being more pronounced in compacted soil. The total $\mathrm{N}_{2} \mathrm{O}$ emission from the control treatment ranged between 0.001 to $0.079 \mathrm{~kg} / \mathrm{ha} / \mathrm{d}$. The nitrate treatment resulted in higher $\mathrm{N}_{2} \mathrm{O}$ emission ranging from 0.01 to 14.02 $\mathrm{kg} / \mathrm{ha} / \mathrm{d}$. There were no significant difference in $\mathrm{N}_{2} \mathrm{O}$ emissions from urine, ammonium and urea treated pasture. Nitrate provided a ready source of $\mathrm{N}$ for denitrification to occur, whereas, for the rest of the sources $\mathrm{N}$ must undergo nitrification prior to denitrification. Rates of nitrification in grassland soils are relatively slow compared with the process of denitrification (Abbasi \& Adams 1998). The high soil moisture conditions that prevailed under compacted soil in the beginning of the 
Figure $5 \quad \mathrm{~N}_{2} \mathrm{O}$ fluxes $(\mathrm{kg} \mathrm{N} / \mathrm{ha} / \mathrm{d})$ under the nitrate treatment for compacted \& uncompacted soils. Each value represents a mean of four replicates with standard deviation shown by vertical bars.

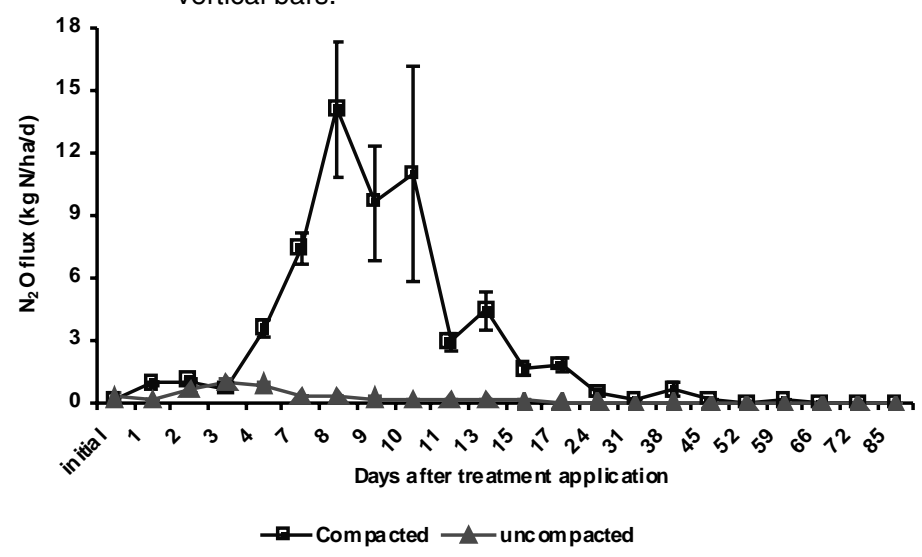

correlate them with the $\mathrm{N}_{2} \mathrm{O}$ emissions, the results of which will be discussed in a subsequent paper.

\section{Conclusions}

Soil compaction caused a seven-fold increase in the $\mathrm{N}_{2} \mathrm{O}$ flux. Highest emissions were measured with nitrate application. From the compacted soil, about $10 \%$ of the total $\mathrm{N}$ applied as nitrate was emitted whereas the emission was $0.5 \%$ from the uncompacted soil. There were no significant differences in emissions among the other three sources (urine, ammonium and urea), which were about one-tenth and one-third of those from nitrate in the compacted experiment further hindered the nitrification process. Thus the fluxes and total losses of $\mathrm{N}$ may be expected to be lower than under normal soil conditions.

Both under compacted and uncompacted soils the nitrate treatment emitted the highest amount of $\mathrm{N}_{2} \mathrm{O}$ (Figure 5). The percentage values of added $\mathrm{N}$ lost as $\mathrm{N}_{2} \mathrm{O}$ are $9.87 \%, 1.09 \%, 1.09 \%$ and $1.08 \%$ for nitrate, urine, ammonium and urea, respectively. Under uncompacted soil, nitrate source emitted the highest percent of the total $\mathrm{N}$ applied, though the emission was not as high as in compacted soil. The values were $0.54 \%, 0.30 \%, 0.25 \%$ and $0.16 \%$ for nitrate, urine, ammonium and urea, respectively. Abassi \& Adams (2000) reported that $\mathrm{N}_{2} \mathrm{O}$ emissions from soils to which nitrate had been added were 3-8 times greater than those where ammonium was added. McTaggart et al. (1997) and Velthof et al. (1997) drew similar conclusions from $\mathrm{N}_{2} \mathrm{O}$ measurements from grassland soils.

Soil compaction restricts oxygen diffusion within the soil, and may lead to changing $\mathrm{N}$ transformations and particularly increased $\mathrm{N}_{2} \mathrm{O}$ production rates (Oenema et al. 1997). Due to restricted soil aeration, high release of $\mathrm{N}_{2} \mathrm{O}$ occurred, especially in cases where soil $\mathrm{NO}_{3}$ concentration was not a limiting factor. Results were supported by the findings of Bakken et al. (1987) and Hansen et al. (1993). They found significantly higher gaseous $\mathrm{N}$ losses from compacted than from uncompacted soil.

Nitrous oxide loss was found to decrease progressively from the time of application of various sources except for nitrate. This was different for both compacted and uncompacted soils and for all the sources applied (Figures 3, 4 and 5).

Other soil parameters (i.e. soil nitrate, ammonium and extractable organic carbon) were measured to and uncompacted soils, respectively. These emissions may represent the maximum potential loss of $\mathrm{N}$ as the soils remained wet during most of the study period. Our preliminary results from a current study where $\mathrm{N}$ was applied under dry soil conditions also indicate very low emissions.

The differences between $\mathrm{N}_{2} \mathrm{O}$ emissions from compacted and uncompacted soil are so large that the relationship between the period of grazing and climatic conditions will be important in determining actual $\mathrm{N}_{2} \mathrm{O}$ loss. Research to quantify $\mathrm{N}_{2} \mathrm{O}$ loss from New Zealand pastures will have to consider this and should be designed to accommodate the temporal and spatial variability including age of urine spot, soil compaction, soil moisture and temperature conditions.

\section{REFERENCES}

Abbasi, M.K.; Adams, W.A. 1998. Loss of nitrogen in compacted grassland soil by simultaneous nitrification and denitrification. Plant \& Soil 200: 265-277.

Abbasi, M.K.; Adams, W.A. 2000. Gaseous N emission during simultaneous nitrification-denitrification associated with mineral $\mathrm{N}$ fertilization to a grassland soil under field conditions. Soil Biology \& Biochemistry 32: 1251-1259.

Adams, W.A.; Akhtar, N. 1994. The possible consequences for herbage growth of waterlogging compacted pasture soils. Plant \& Soil 162: 1-17.

Arah, J.R.M.; Smith, K.A.; Crichton, I.J.; Li, H.S. 1991. Nitrous-oxide production and denitrification in Scottish soils. Journal of Soil Science 42: 351-367.

Bakken L. R.; Borresen T.; Njos A. 1987. Effect of soil compaction by tractor traffic on soil structure, denitrification, and yield of wheat (Triticum aestivum L.). Journal of Soil Science 38: 541-552. 
Ball,B.C.; Parker, J.P.; Scott, A. 1999. Soil and residue management effects on cropping conditions and nitrous oxide fluxes under controlled traffic in Scotland 2. Nitrous oxide, soil N status and w eather. Soil \& Tillage Research 52: 191-201.

Ball, B.C.; Horgan, G.W.; Parker, J.P. 2000. Shortrange spatial variation of nitrous oxide fluxes in relation to compaction and straw residues. European Journal of Soil Science 51: 607-616.

Betteridge, K.; MacKay, A.D.; Shepherd, T.G.; Barker, D.J.; Budding, P.J.; Devantier, B.P.; Costall, D.A. 1999. Effect of cattle and sheep treading on surface configuration of a sedimentary hill soil. Australian Journal of Soil Science 37: 743-760.

Chancellor, W.J.; Schmidt, R.H.; Soehne, W. 1962. Laboratory measurement of soil compaction and plastic flow. Transactions of the American Society of Agricultural Engineers 5: 235-239.

Crutzen P.J. 1976. The influence of nitrous oxides on the atmospheric ozone content. Quarterly Journal of the Royal Meterological Society 96: 320-325.

Douglas, J.T.; Crawford, C.E. 1993. The response of a ryegrass sward to wheel traffic and applied nitrogen. Grass and Forage Science 48: 91-100.

Finlayson, J.D.; Betteridge, K.; MacKay, A.; Thorrold, B.; Singleton, P.; Costall, D.A. 2002. A simulation model of the effects of cattle treading on pasture production on North Island, New Zealand, hill land. New Zealand Journal of Agricultural Research 45: 255-272.

Fraser, D.J.; Doran, J.W.; Sahs, W.W.; Lesoing, G.W. 1988. Soil microbial-populations and activities under conventional and organic management. Journal of Environmental Quality 17: 585-590.

Glinski, J.; Stephanie, W. 1985. Soil aeration and its rate for plants. CRC pres, Boca Raton, Florida.

Hansen. S.; Maehlum J.E.; Bakken, L.R. 1993. $\mathrm{N}_{2} \mathrm{O}$ and $\mathrm{CH}_{4}$ fluxes in soil influenced by fertilization and tractor traffic. Soil Biology \& Biochemistry 25: 621-630.

Hewitt, A.E. 1993. New Zealand soil classification, Landcare Research Science Series, Dunedin. 132 pp.

Koops, J.G.; Oenema, O. 1994. Nitrogen losses from grassland on peat soil through denitrification. pp. 418-422. In: Proceedings $15^{\text {th }}$ General Meeting, European Grassland Federation.

Lemon, E.R.; Erickson, A.E. 1952. The measurement of oxygen diffusion in the soil with a platinum microelectrode. Soil Science Society of America Proceedings 16: 160-163.

Lemon, E.R.; Erickson A.E. 1955. Principle of the platinum microelectrode as a method of characterizing soil aeration. Soil Science 79: 383392.
Linn, D.M.; Doran, J.W. 1984. Aerobic and Anaerobic Microbial populations in no-Till and plowed soils. Soil Science Society of America Journal 48 : 794-799.

McTaggart, I.P.; Clayton, H.; Parker, J.; Swan, L.; Smith, K.A. 1997. Nitrous oxide emissions from grassland and spring barley, following $\mathrm{N}$ fertiliser application with and without nitrification inhibitors. Biology and Fertility of Soils 25: 261-268.

Mosier, A.R.; Mack, L. 1980. Gas chromatographic system for precise, rapid analysis of nitrous oxide. Soil Science Society of America Journal 44: 11211123.

Mosier, A.R.; Guenzi, W.D.; Schweizer, E.E. 1986. Soil losses of dinitrogen and nitrous oxide from irrigated crops in northeastern Colorado. Soil Science Society of America Journal 50: 344-348.

Oenema, O.; Velthof, G.L.; Yamulki, S.; Jarvis, S.C. 1997. Nitrous oxide emissions from grazed grassland. Soil Use and Management 13: 288-295.

Ruser, R.; Flessa, H.; Schillling, R.; Steindl, H.; Beese, F. 1998. Soil compaction and fertilization effects on nitrous oxide and methane fluxes in potato fields. Soil Science Society of America Journal 62 : 15871595.

Saggar, S.; Andrew, R.M.; Tate, K.R.; Rodda, N.J.; Hedley, C.B.; Townsend, J.A. 2002. Measurements and modelling of nitrous oxide emissions from dairy pastures. pp. 201-214. In: Proceedings of the workshop on Dairy Farm Soil Management.

Staley, T.E.; Caskey, W.H.; Broyer, D.G. 1990. Soil denitrification and nitrification potentials during the growing season relative to tillage. Soil Science Society of America Journal 54: 1602-1608.

Thomas, R.F.; Mew, G.; Barker, P.R. 1990. Effect of different drainage systems in bearing resistance of some West Coast, South Island soils. New Zealand Journal of Agricultural Research 33: 479-488.

Tobert, H.A.; Wood, C. W. 1992. Effects of soil compaction and water-filled pore space on soil microbial activity and $\mathrm{N}$ losses. Communications in Soil Science and Plant Analysis 23: 1321-1331.

Tollner,E.W.; Clavert,G.V.; Langdale,G. 1990. Animal trampling effects on soil physical properties of southeastern U.S. ultisols. Agriculture, Ecosystems and Environment 33: 75-87.

Velthof, G.L.; Oenema, O.; Postma, R.; Van, Beusichem, M.L. 1997. Effect of type and amount of applied nitrogen fertilizer on nitrous oxide fluxes from intensively managed grassland. Nutrient Cycling in Agroecosystems 46: 257-267.

Willatt, S.T.; Pullar, D.M. 1983. Changes in soil physical properties under grazed pastures. Australian Journal of Soil Research 22: 343-348. 